\title{
РОЛЬ ПРЕЗИДЕНТА РОССИИ В МЕХАНИЗМЕ РЕАЛИЗАЦИИ КОНСТИТУЦИОННЫХ ПРИНЦИПОВ ФЕДЕРАЛИЗМА, ЕДИНСТВА ГОСУДАРСТВЕННОЙ ВЛАСТИ И РАЗДЕЛЕНИЯ ВЛАСТЕЙ
}

\begin{abstract}
Аннотация: Рассмотрены основные направления осуществления полномочий и показана роль Президента РФ в механизме реализации конституционных принципов разделения властей, единства государственной власти и федерализма, проведен анализ законодательства и правовых позиций Конституционного Суда РФ, раскрывающих компетенцию главы государства в обозначенных сферах.Предложены меры по оптимизации полномочий Президента РФ, сформулирован вывод о необходимости ограничения его полномочий в системе разделения властей и федеративных отношениях.
\end{abstract}

Ключевые слова: Юриспруденция, Президент России , разделение властей, единство государственной власти, федерализм, Конституция РФ, правовые позищии, Конституционный Суд РФ, арбитр, конституционализм

$\mathrm{B}$ ажнейшим правовым фундаментом организации и деятельности всего государственного аппарата являются принципы конституционного строя, определяющие конституционные приоритеты и ценности, закрепленные в главе 1 Конституции РФ. Среди таковых непосредственное отношение к организации государственной власти имеют конституционные принципы федерализма (ст. 1, 5 Конституции РФ), разделения властей (ст. 10, 11 Конституции РФ) и единства системы государственной власти (ст. 5 Конституции РФ).

\section{Принципы единства государственной власти и разделения властей в системе российского федерализма}

Если первым двум принципам уделено достаточно внимания в литературе, то принцип единства государственной власти являясь принципом российского федерализма существенно влияет на федеративную структуру Российского государства, где ключевое место занимает Президент России.

Принцип единства системы государственной власти означает ее единый источник (народ), единые цели, систему и принципы организации и функционирования государственного аппарата, который цементируется единством и слаженностью работы всех государственных органов. Кроме того, единство государственной власти выражается в единстве направлений внутренней и внешней политике, которые определяет глава госу- дарства и реализуют органы государственной власти, в наличии механизмов координации государственной деятельности и институтов федерального представительства в федеративном государстве.

Вместе с тем, возникает вопрос - насколько закрепленный в Конституции РФ принцип разделения властей сочетается с принципом единства системы государственной власти? Не противоречат ли они друг другу? В этой части следует согласиться с В.Е. Чиркиным, который подчеркнул, что разделение властей требует единства государственной политики, единства действий всех ветвей по принципиальным вопросам общественного развития, а единство власти не исключает «прозаического разделения труда» между различными органами государственной власти. Наиболее плодотворным подходом конституционного права в современных условиях является соединение идей единства и разделения властей, их взаимодействия и системы сдержек и противовесов. Такое понимание отражено и в современных конституциях. Например, п. 4 ст. 3 Конституции Казахстана 1995 г. гласит: «Государственная власть в Республике Казахстан едина, осуществляется на основе Конституции и законов в соответствии с принципом ее разделения на законодательную, исполнительную и судебную ветви и взаимодействия их между собой с использованием системы сдержек и противовесов». ${ }^{1}$

1 Чиркин В.Е. Конституционное право зарубежных стран. M., 2005. C. 160-161. 


\section{Политика и общество 3 (99) • 2013}

Следовательно, принципы единства системы государственной власти и разделения властей не противоречат друг другу, а при правильном конституционном оформлении, организации и практической реализации вполне могут гармонично сочетаться и эффективно работать в государственном механизме, в котором ведущую роль выполняет Президент России, обладая весьма обширными полномочиями не только в сферах законодательной, исполнительной и судебной власти, но и в отношениях с субъектами РФ.

\section{Президент России в системе разделения властей}

Не вдаваясь в полемику о необходимости сильной президентской власти в России, ограничимся констатацией ее наличия. Из анализа Конституции РФ следует, что Президент РФ занимает особое место в системе органов государственной власти, не входит непосредственно ни в одну из ее ветвей, а скорее условно становится над ними. В прежней Конституции РСФСР его статус определялся через термины «высшее должностное лицо» и «глава исполнительной власти». В Конституции РФ 1993 г. Президент РФ определяется как глава государства и в этом качестве является гарантом Конституции РФ, прав и свобод человека и гражданина.

Конституция РФ, закрепляя правовой статус Президента РФ, определяет его основные функции, порядок его избрания, компетенцию, основания прекращения полномочий и процедуру отрешения его от должности. Кроме того, Конституция РФ закрепляет неприкосновенность Президента РФ. ${ }^{2}$

Следует заметить, что перечень оснований прекращения полномочий главы государства, закрепленный в Конституции РФ, не является исчерпывающим. Помимо смерти, основанием прекращения полномочий Президента РФ является и утрата им гражданства РФ. ${ }^{3}$

\footnotetext{
${ }^{2}$ См. подр.: Сопельцева, Н.С. Иммунитеты в конституционном праве Российской Федерации / Н.С. Сопельцева. - Челябинск, 2004; Безруков, А.В. Правовой статус Президента Российской Федерации : учебное пособие / А.В. Безруков, С.А. Пунтус. - Красноярск, 2005.

3 Важна здесь и правовая позиция Конституционного Суда РФ, который определил, что временное исполнение обязанностей Президента РФ возлагается на Председателя Правительства РФ во всех случаях, когда объективно исключено исполнение своих функций Президентом РФ. Следовательно, могут возникнуть непредвиденные обстоятельства, которые законодательно в полном объеме невозможно предусмотреть. См.: Постановление Конституционного Суда РФ от 06 июля 1999 г. по делу о толковании ч. 2 и 3 ст. 92 Конституции РФ // Консультант плюс.
}

Конституционный статус реализуется в нормах Конституции РФ, определяющих функиии и полномочия главы государства. Эти два понятия очень близки друг к другу, но не тождественны. Из первых следуют вторые.

Основные функиии Президента РФ как главы государства определены ст. 80 Конституции РФ. Первая из основных функций Президента РФ - быть гарантом Конституции РФ. В силу этой функции на Президента РФ возлагается ряд полномочий по правовой охране Конституции РФ. На основании этого глава государства обращается к любому федеральному или региональному органу власти с предложением привести свои акты или действия в соответствие с Конституцией РФ и законодательством, приостанавливает действие актов органов исполнительной власти субъектов РФ в случае их противоречия Конституции РФ и законодательству, обращается с запросами в Конституционный Суд РФ и т.д.

На Президента как на главу государства и гаранта Конституции РФ возлагается его обязанность обеспечивать включение в конституционный текст поправок и изменений посредством официального опубликования актов, принятых в порядке статей 136 и 137 Конституции РФ. ${ }^{4}$

Еще большими полномочиями обладает Президент РФ как гарант прав и свобод человека и гражданина. В случае ущемления, ограничения или нарушения прав и свобод личности Президент РФ не только вправе, но просто обязан принять меры по устранению подобных явлений. Глава государства наделен для этого широкими полномочиями вплоть до введения военного или чрезвычайного положения в стране.

Столь же широко сформулирована в Конституции РФ функция Президента по охране суверенитета Российской Федерации, ее независимости и государственной целостности.

Очень важна функция Президента РФ по обеспечению согласованного функциионирования и взаимодействия органов государственной власти. В отличие от ряда стран в Конституции РФ Президент РФ не называется «арбитром» во взаимоотношениях трех ветвей власти. Как глава государства, находясь вне законодательной, исполнительной и судебной власти, по суще-

\footnotetext{
${ }^{4}$ См.: По делу о толковании части 2 статьи 137 Конституции РФ: Постановление Конституционного Суда РФ от 28 ноября 1995 года №15-П // Собрание законодательства РФ. - 1995. - №49. - Ст. 4868.
} 
ству, Президент РФ как раз и есть арбитр между различными уровнями и ветвями власти. Реализации этой функции способствует полномочие Президента РФ прибегать к согласительным процедурам и другим мерам преодоления кризисов и разрешения споров.

Конституция РФ возлагает на Президента РФ функцию определения основных направлений внутренней и внешней политики государства, оговаривая, однако, что эта функция должна осуществляться в соответствии с Конституцией и федеральными законами. Реализация же данной политики осуществляется в первую очередь исполнительными органами власти.

При выработке внутреннего и внешнеполитического курса глава государства должен руководствоваться результатами законодательной деятельности. Следовательно, в разработке государственной политики существенное влияние оказывает Федеральное Собрание РФ.

Внешнепредставительские функции главы государства выражаются в его взаимодействии с главами других государств, подписании международных договоров и др. Представительство внутри страны осуществляется через полномочных представителей Президента РФ в федеральных округах и органах государственной власти (Конституционном Суде РФ, палатах российского парламента).

Что касается особенностей полномочий главы государства, которые конкретизирую его функции, то здесь важно обратить внимание на два момента. Во-первых, Конституция РФ содержит лишь основные полномочия Президента РФ, которые существенно расширены законодателем и указами Президента РФ. Во-вторых, Президент обладает так называемыми «скрытыми», дискреционными полномочиями, которые прямо не закреплены в Конституции РФ, имплицитно содержатся в ней и вытекают из смысла президентских функций, которые проявляются в непредвиденных экстраординарных условиях, что и подтвердил Конституционный Суд в решении по «чеченскому» делу. ${ }^{5}$ Принципиально важно, что Суд установил, что применение «скрытых» полномочий возможно только в условиях соответствия Конституции РФ и федеральным законам, и только в рамках принципа разделения властей, что означает функциональное предназначение таких полномочий для главы государства и исключает его вторжение в компетенцию других государственных органов.

5 Постановление Конституционного Суда РФ от 31 июля 1995 года № 10-П // Консультант плюс.
Небесспорность такого решения Суда подтверждается критикой не только известных ученых ${ }^{6}$, но и тем, что семь судей выразили свое особое мнение по данному делу. Опасность такой правовой позиции Суда действительно заключается в том, что субъекта права сам уточняет и устанавливает пределы своей компетенции.

Представляется, что многообразие конкретных жизненных ситуаций и роль Президента как гаранта Конституции, прав и свобод человека влекут за собой ответственность главы государства за конституционный порядок, что дает основания для признания возможности позиции о наличии «скрытых» полномочий главы государства. Однако важно закрепить конституционные механизмы политико-правового сдерживания реализации «скрытых» полномочий Президента со стороны других ветвей власти, где судебная власть дает правовую оценку их конституционности, а законодательная и исполнительная власти в лице спикеров палат парламента, премьер-министра проводят с Президентом официальные консультации относительно возможности их реализации, как к примеру, предусмотрено в Конституции Франции (ст. 16).

В развитие такой правовой позиции в последующем решении Конституционный Суд РФ подтвердил право Президента РФ восполнять пробелы в законодательстве посредством издания им нормативных указов при условии их временного характера и соответствия Конституции РФ и законодательству, что, безусловно, расширяет его «скрытые» полномочия. ${ }^{7}$

По специфике компетенции и взаимоотношений с другими органами государственной власти полномочия Президента РФ могут быть разбиты на несколько групп. ${ }^{8}$ Реализация его полномочий осуществляется с учетом принципа разделения властей, следовательно, можно выделить полномочия Президента РФ в сфере законодательной, исполнительной и судебной власти.

\footnotetext{
${ }^{6}$ См. например: Краснов М.А., Шаблинский И.Г. Российская система власти: треугольник с одним углом М., 2008. С. 46-48. Лучин В.О. «Указное право» в России М., 1996. С. 38-40.

7 Постановление Конституционного Суда РФ от 30 ноября 1996 года № 11-П // Консультант плюс.

${ }^{8}$ Схожие классификации групп полномочий Президента РФ представлены в нескольких учебниках по конституционному праву. Напр.: Конституционное право России / отв. ред. А.Н. Кокотов, М.И. Кукушкин. М., 2008. - С.348-354; Баглай, М.В. Конституционное право Российской Федерации : учебник для вузов / М.В.Баглай. - М., 2004. - С.425-440.
} 


\section{Политика и общество 3 (99) • 2013}

Полномочия Президента РФ в сфере законодательной власти. Для совершенствования сотрудничества главы государства и палат федерального парламента Президент РФ назначает своих полномочных представителей в Совет Федерации и Государственную Думу. К полномочиям Президента РФ также относится:

1) участие Президента РФ в законодательном процессе. К подобным полномочиям относятся: право быть субъектом законодательной и конституционной инициативы (ст.104, 134 Конституции РФ), право относительного вето на принятые федеральные законы (преодолевается квалифицированным большинством каждой из палат Федерального Собрания РФ), подписание и обнародование принятых законов (ст.107 Конституции РФ);

2) назначение выборов депутатов Государственной Думы;

3) ежегодное обращение к Федеральному Собранию с посланием о положении в стране, об основных направлениях внутренней и внешней политики государства. С учетом законодательной неопределенности правовой природы посланий Президента РФ парламенту интересна точка зрения, согласно которой, с одной стороны, общие установки и конкретные поручения, содержащиеся в послании, имеют общеобязательный характер, а с другой - послание не является нормативным актом, не может противоречить законам, ограничивать правотворческую деятельность парламента; ${ }^{9}$

4) право роспуска Государственной Думы в установленных Конституциях случаях;

5) совместное участие с палатами Федерального Собрания в формировании некоторых органов государственной власти. Президент РФ взаимодействует с палатами парламента при назначении и освобождении от должности Председателя Центрального Банка РФ, Генерального прокурора РФ, членов ЦИК РФ и др.;

6) право роспуска парламентов субъектов РФ в установленных законом случаях и др.

Полномочия Президента РФ в сфере исполнительной власти. Наиболее тесным является сотрудничество главы государства с исполнительной властью. К подобным полномочиям относятся:

1) назначение Председателя Правительства РФ с согласия Государственной Думы (ч.1 ст.111 Конституции РФ);

\footnotetext{
${ }^{9}$ См.: Конституционное право России : учебник./ Отв. ред. А.Н. Кокотов, М.И. Кукушкин С.405.
}

2) утверждение представленных главой Правительства РФ предложений о структуре федеральных органов исполнительной власти (ч.1 ст.112 Конституции РФ);

3) назначение на должность и освобождение от должности по предложению Председателя Правительства РФ заместителей Председателя Правительства РФ и федеральных министров (ч.2 ст.112 Конституции РФ);

4) единоличное принятие решение об отставке Правительства РФ. Президент РФ вправе отправить в отставку Правительство РФ в случае выражения ему недоверия Государственной Думой и в случае отказа в доверии Государственной Думой. Однако глава государства может отправить в отставку высший орган исполнительной власти и по собственному усмотрению. Президент РФ также может принять отставку Правительства РФ и его Председателя;

5) право председательствовать на заседаниях Правительства РФ (п. «б» ст.83 Конституции РФ);

6) право отмены актов Правительства РФ в случае их противоречия Конституции РФ, федеральным законам и указам Президента РФ (ч.3 ст.115 Конституции РФ). В данном случае Президент РФ выступает фактически в качестве органа конституционного контроля;

7) право приостанавливать действие актов органов исполнительной власти субъектов РФ в случае противоречия этих актов Конституции РФ и федеральным законам, международным обязательствам РФ или нарушения прав и свобод человека и гражданина до решения этого вопроса соответствующим судом (ч.2 ст.85 Конституции РФ). В данном же случае можно констатировать, что Президент РФ выступает в качестве органа конституционного надзора и др.

$K$ полномочиям Президента РФ в сфере судебной власти относятся:

1) представление кандидатур для назначения Советом Федерации на должности руководителей и судей Конституционного Суда РФ, Верховного Суда РФ, Высшего Арбитражного Суда РФ (п. «е» ст.83 Конституции РФ);

2) назначение судей других федеральных судов в порядке, установленном федеральным законом (ст. 128 Конституции РФ);

3) право обращения в Конституционный Суд РФ и другие суды (ст.ст.85, 125 Конституции РФ);

4) осуществление помилования (п. «в» ст.89 Конституции РФ);

5) представление кандидатур Генерального прокурора РФ, Председателя Следственного комитета РФ в 
Государство и гражданское общество

Совет Федерации для назначения или освобождения их от должности.

Помимо сфер разделения властей, Президент осуществления свои полномочия и в иных сферах государственной деятельности, таких как обороны и безопасности, международного сотрудничества внешней политики, вопросов гражданства и государственных наград.

\section{Роль Президента России в федеративных отношениях}

Важно обратить внимание на полномочия Президента РФ в сфере взаимодействия с субъектами Федерации, которые способствуют реализации не только принципа федерализма, но и принципа разделения властей по вертикали. Позволяют ли такие полномочия установить баланс между федеральным и региональными органами власти? Насколько они вписываются в рамки Конституции РФ, соответствуют ли ее букве и духу? Полномочия Президента РФ в этой сфере практически не прописаны в Конституции РФ. Они закреплены в соответствующих законах и указах Президента РФ и вытекают из сущности полномочий Президента РФ в целом. В их числе:

1) назначение полномочных представителей Президента РФ в федеральные округа;

2) участие в образовании новых субъектов РФ на этапе согласования объединения;

3) согласительные процедуры между федеральными и региональными органами власти, и между последними;

4) право отрешения от должности глав субъектов РФ и роспуска региональных парламентов в случаях, предусмотренных законом;

5) право приостановления актов органов исполнительной власти субъектов РФ (ч. 2 ст. 85 Конституции РФ). И практика знает такие примеры, когда Президент РФ как гарант Конституции РФ, прав и свобод человека, приостанавливал действия актов Правительства Ленинградской области, администраций Красноярского края, Мурманской и Воронежской областей, а также указов глав ряда республик в составе РФ (Ингушетия, Чувашия, Саха). ${ }^{10}$

И представленный перечень полномочий главы государства далеко не полный. По подсчетам

${ }^{10}$ См.: СААП РФ. - 1994. - 15. См. 1215; СЗ РФ. 1994. № 4. Ст. 305; СЗ РФ. 1995. № 4. Ст. 281; СЗ РФ. 1996. № 4. Ст. 262.
М.А. Краснова, с 2000 по 2011 г. Президент РФ законодательно оформил за собой 115 полномочий, которые выходят за рамки предусмотренных Конституцией РФ. При этом, М.А. Краснов показывает интересную динамику роста числа неконституционных полномочий, установленных в периоды правления всех трех Президентов РФ. ${ }^{11}$

Действительно, за последние годы на законодательном и подзаконном уровне колоссально расширены полномочия Президента РФ, особенно в части формирования органов государственной власти, что ограничивает эффективную реализацию конституционных принципов федерализма и разделения властей. Среди таких полномочий переход права самостоятельно выдвигать кандидатуры руководителей и аудиторов Счетной палаты РФ от палат парламента к Президенту РФ; выдвижение кандидатур Председателя Конституционного Суда РФ и его заместителей, как и досрочное прекращение их полномочий Советом Федерации по представлению Президента РФ, что прежде относилось к компетенции самого Суда и обеспечивало ему уникальный статус и набольшую независимость; создание ряда органов, позволяющих Президенту расширить свое влияние на субъекты РФ (Государственный Совет, полпреды в федеральных округах); право формировать высшее руководство государственных корпораций (Росатом, Ростехнологии, Внещэкономбанк) и назначать ректоров двух ведущих вузов - МГУ и СПбГУ; расширение функций и структуры Администрации Президента РФ. ${ }^{12}$

Нельзя не заметить и практики «персонификации» отдельных правовых норм под конкретных должностных лиц (возможность отсутствия высшего юридического образования для главы ЦИК России (поправка 2007 г. в Ф3 об основных гарантиях избирательных прав граждан), возможность сочетания статуса полпреда Президента РФ в федеральном округе и заместителя Председателя Правительства РФ (поправка 2010 г. в ФКЗ о Правительстве РФ), отмена ограни-

${ }^{11}$ См.: Краснов М.А. Законодательно закрепленные полномочия Президента России: необходимость или сервилизм // Сравнительное конституционное обозрение. - 2011.- № 4. C. $7-8$.

${ }^{12}$ См. подр: Краснов М.А. Указ. соч. С. 7-10.; Кондрашев А.А. Особенности современного формирования политической системы России в контексте характеристики государственного режима // Конституционное и муниципальное право. 2012. № 5. С. 29-31; Лебедев В.А. Компетенция Президента Российской Федерации // Проблемы права. 2012. № 3. С. 11-13. 


\section{Политика и общество 3 (99) • 2013}

чения предельного возраста для пребывания в должности Председателя Конституционного Суда РФ (поправка 2010 г. в ФКЗ о Конституционном Суде РФ).

Особенно расширение полномочий главы государства распространилось на сферу отношений с субъектами Федерации, о чем выше отмечалось. Конституционный Суд еще в 2002 году подтвердил конституционность установленных федеральным законодателем правомочий по роспуску Президентом региональных парламентов, отрешению от должности в установленном законом порядке и временному отстранению от исполнения обязанностей руководителей субъектов РФ. ${ }^{13}$ Однако в последующем единая вертикаль власти еще в большей мере ограничивает принцип федерализма, что выразилось в отмене выборов глав субъектов РФ, расширении оснований для роспуска регионального парламента (в случае отказа в согласовании кандидатуры руководителя региона) и отрешения от должности главы региона Президентом РФ (утрата доверия Президента, выражение недоверия парламентом субъекта РФ, ненадлежащее исполнение своих обязанностей).

И, несмотря на то, что законодатель уже вернул прямые выборы глав регионов, пусть и в модифицированном виде, есть ли смысл доказывать, что перекос полномочий в пользу президентской власти сохраняется? Само по себе детальное регулирование вопросов организации законодательных и исполнительных органов власти субъектов РФ федеральным законом идет вразрез с конституционными принципами федерализма и самостоятельности субъектов РФ в установлении системы своих органов государственной власти (ст.ст. 5, 11, 77 Конституции РФ).

Разумеется, что самостоятельность субъектов РФ в формировании своих органов власти не может быть абсолютной. Но и участие Федерации в таком вопросе вряд ли может сводиться к полному правовому регулированию. Порядок избрания не менее половины депутатов парламента субъекта РФ, процедура замещения должности главы субъекта РФ, меры ответственности региональных органов власти исчерпывающим образом регламентированы федеральным законодателем. Что остается субъектам РФ? При всей дискуссионности обозначенных вопросов очевидно главное - содержание названного рамочного ФЗ однозначно выходит за рамки его

\footnotetext{
${ }^{13}$ Постановление Конституционного Суда РФ от 04 апреля
} 2002 года № 8-П // Консультант плюс. названия, не ограничивается установлением «общих принципов» и во многом подменяет предмет региональных правовых актов. ${ }^{14}$

В соответствии с данным законом гарантируется система сдержек и противовесов, закрепляется самостоятельность государственных органов всех ветвей власти (ст.23); отсутствует общая подотчетность исполнительной власти по всем вопросам ее компетенции власти законодательной. Принцип же единства системы государственной власти выражается, видимо в том, что субъекты РФ должны исходить из федеральной схемы взаимоотношений исполнительной и законодательной власти.

В тоже время, нельзя не признать позитивный вклад Президента РФ в формирование федеративных отношений, что проявляется в создании условий для благополучного развития субъектов РФ, оказании им поддержки со стороны Федерации, учете интересов субъектов РФ на федеральном уровне, выстраивании конструктивных отношений между органами власти Федерации и ее субъектов, а также между регионами, участии Президента России в процедурах образования нового субъекта РФ.

$$
* * *
$$

Весьма обширные полномочия главы государства как в системе разделения властей, так и в федеративных отношениях свидетельствует о нарушении системы сдержек и противовесов, положенной в основу принципа разделения властей, не позволяющей установить необходимый баланс полномочий как между органами законодательной, исполнительной и судебной власти, так и между федеральными и региональными органами. Однако такой подход логично вписывается в концепцию единства системы государственной власти. Нарушает ли это принцип федерализма? Здесь следует разделить мнение о том, что покушение на федерализм состоит в том, что понятие «единство системы государственной власти» у нас сведено к иерархии, поскольку законодательно признано, что на уровне субъектов РФ без федерального Президента не могут действовать обычные для системы разделения властей институты. ${ }^{15}$

${ }^{14}$ См. подр. Безруков А.В. Модернизация государственного управления и системы органов государственной власти субъектов РФ // Проблемы права. 2012. № 3. С. 35-41.

${ }^{15}$ Краснов М.А., Щаблинский И.Г. Указ. соч. С. 82-83. 
Таким образом, роль Президента РФ в реализации конституционных принципов федерализма, разделения властей и единства системы государственной власти проявляется по-разному. Если укрепление вертикали власти и расширение полномочий Президента РФ логично вписывается в обеспечение конституционного принципа единства системы государственной власти, то концентрация и подконституционное расширение властных полномочий Президента РФ не всегда соответствует конституционным принципам федерализма и разделения властей.

\section{Библиография:}

1. Баглай, М.В. Конституционное право Российской Федерации : учебник для вузов / М.В.Баглай. М., 2009.

2. Безруков А.В. Модернизация государственного управления и системы органов государственной власти субъектов РФ // Проблемы права. 2012. № 3.

3. Безруков, А.В. Правовой статус Президента Российской Федерации : учебное пособие / А.В. Безруков, С.А.Пунтус. - Красноярск, 2005.

4. Краснов М.А. Законодательно закрепленные полномочия Президента России: необходимость или сервилизм // Сравнительное конституционное обозрение. - 2011.- № 4.

5. Краснов М.А., Шаблинский И.Г. Российская система власти: треугольник с одним углом М., 2008.

6. Конституционное право России / отв. ред. А.Н.Кокотов, М.И.Кукушкин. М., 2008.

7. Кондрашев А.А. Особенности современного формирования политической системы России в контексте характеристики государственного режима // Конституционное и муниципальное право. 2012. № 5 .

8. Лебедев В.А. Компетенция Президента Российской Федерации // Проблемы права. 2012. № 3.
9. Лучин В.О. «Указное право» в России М., 1996.

10. Сопельцева, Н.С. Иммунитеты в конституционном праве Российской Федерации / Н.С.Сопельцева. Челябинск, 2004;

11. Чиркин В.Е. Конституционное право зарубежных стран. М., 2005.

\section{References (transliteration):}

1. Baglay, M.V. Konstitutsionnoe pravo Rossiyskoy Federatsii : uchebnik dlya vuzov / M.V.Baglay. - M., 2009.

2. Bezrukov A.V. Modernizatsiya gosudarstvennogo upravleniya i sistemy organov gosudarstvennoy vlasti sub’ektov RF // Problemy prava. 2012. № 3.

3. Bezrukov, A.V. Pravovoy status Prezidenta Rossiyskoy Federatsii : uchebnoe posobie / A.V.Bezrukov, S.A.Puntus. - Krasnoyarsk, 2005.

4. Krasnov M.A. Zakonodatel'no zakreplennye polnomochiya Prezidenta Rossii: neobkhodimost' ili servilizm // Sravnitel'noe konstitutsionnoe obozrenie. 2011.- № 4.

5. Krasnov M.A., Shablinskiy I.G. Rossiyskaya sistema vlasti: treugol'nik s odnim uglom M., 2008.

6. Konstitutsionnoe pravo Rossii / otv. red. A.N. Kokotov, M.I.Kukushkin. M., 2008.

7. Kondrashev A.A. Osobennosti sovremennogo formirovaniya politicheskoy sistemy Rossii v kontekste kharakteristiki gosudarstvennogo rezhima // Konstitutsionnoe i munitsipal'noe pravo. 2012. № 5.

8. Lebedev V.A. Kompetentsiya Prezidenta Rossiyskoy Federatsii // Problemy prava. 2012. № 3.

9. Luchin V.O. «Ukaznoe pravo» v Rossii M., 1996.

10. Sopel'tseva, N.S. Immunitety $\mathrm{v}$ konstitutsionnom prave Rossiyskoy Federatsii / N.S.Sopel'tseva. Chelyabinsk, 2004;

11. Chirkin V.E. Konstitutsionnoe pravo zarubezhnykh stran. M., 2005. 